\title{
Incorporating Culture and Mother Tongue in Mathematics Learning : Counting Operation in Traditional Houses Using Banyuwangi
}

\author{
Rachmaniah M. Hariastuti ${ }^{1^{*}}$, Mega T. Budiarto ${ }^{2}$, and Manuharawati ${ }^{2}$ \\ ${ }^{1}$ Continuing Program Development, Universitas Negeri Surabaya, Surabaya, Indonesia, 60213 \\ ${ }^{1}$ Department of Mathematics Education, Universitas PGRI Banyuwangi, Banyuwangi, Indonesia, 68418 \\ ${ }^{2}$ Department of Mathematics Education, Universitas Negeri Surabaya, Surabaya, Indonesia, 60213 \\ *Corresponding author: mirzarachmania@gmail.com | Phone Number: +6281330920082
}

\section{ARTICLE HISTORY}

Received : 29 April 2020

Revised : 20 June 2020

Accepted : 18 September 2020

\section{KEYWORDS}

House of using banyuwangi; Development of teaching;

Mother tongue;

Elemnetary school;

\begin{abstract}
House of Using Banyuwangi is one of the cultural components of the Using tribe in Banyuwangi-Indonesia which contains a lot of mathematical concepts. The existence of mathematical concepts in culture, commonly known as ethnomathematics, can be the basis for the development of mathematics teaching materials for elementary school. In addition to the application of cultural components in the form of Using traditional houses, the use of Using language as a language of learning can also be a bridge for students to be able to more easily understand mathematical concepts that are still abstract.
\end{abstract}

This is an open access article under the CC-BY-SA license.

\section{INTRODUCTION}

Banyuwangi is one of the regions in Indonesia which has designation "the sunrise of Java". Banyuwangi is located in the eastermost region of Java island. The native tribe in Banyuwangi is known as the Using tribe. Cultural diversity in Banyuwangi contains a variety of knowledge both tangible and disguised. Using Banyuwangi's cultural diversity not only holds high artistic values but also includes learning concepts. As in the culture of the following Banyuwangi Angklung and Gandrung dance.

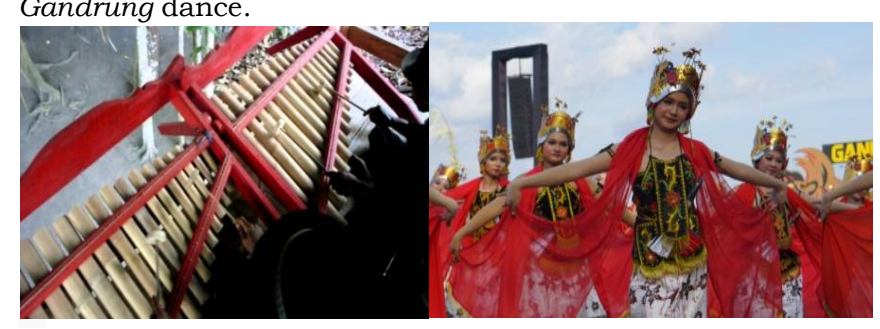

Fig. 1. Banyuwangi Angklung and Gandrung Dance

The result of identification carried out by Hidayatulloh $\&$ Hariastuti (2018:388) stated that " in the process of making and the shape of Angklung shows the existence of two and three dimensional geometry concepts, traditional measurement units, and measurement concepts". As shown in Figure 1 (left) it appears that the angklung blades which are tube-shaped with decreasing size (from left to right) with a certain ratio. The exploration done of Gandrung Jejer Jaran Dawuk dance shows that in the dance there are mathematical concepts, such as: introduction of angles, transformation (reflection), line patterns, trapezoidal patterns, triangular patterns, and pentagonal patterns (Sandhi, et.al., 2018:165-168).
Besides Angklung and Gandrung dance, the Using Banyuwangi tribe community also has a variety of other cultures, including traditional houses. The house of Using Banyuwangi community is called the house of Using. House of Using is part of the culture that contains the moral and social values of the Using Banyuwangi tribe.

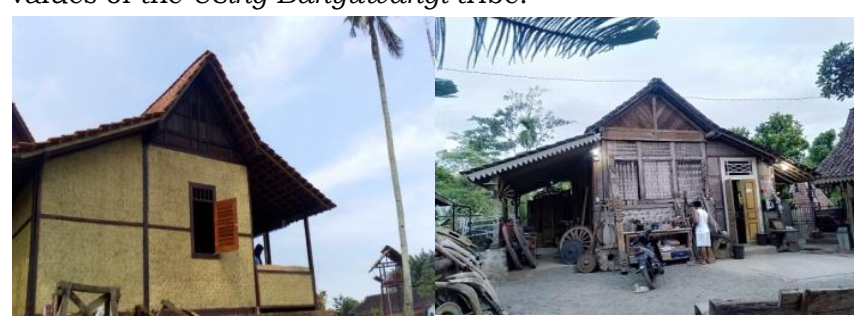

Fig. 2. House of Using Banyuwangi

Wibowo (2015:63-64) state that "in general the house of Using Banyuwangi is divided into three types based on the shape of the roof that called rab (roof section), namely tikel balung (has four $r a b$ ), cerocogan (has three rab), and baresan (has two rab)".

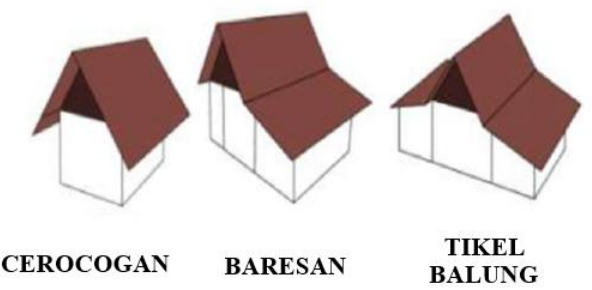

Fig. 3. Types of House of Using Banyuwangi Based on the Shape of the Roof (Nur, dkk., 2010:66). 
The main structure of the house of Using Banyuwangi has a frame consisting of four main wooden pillars called soko, frame with a tanding system without nails but using flat pegs called paju, roof cover using the village tile, usually still used dirt floors, and the walls and partitions of the house still use woven bamboo called gedheg (Indiarti, 2015:146).

Hariastuti, et al. (2019:78) explained from their research that the house of Using Banyuwangi still uses the following components.

Long wood above the house is called suwunan. Two short-standing logs are called ander. The wood that forms the sloping sides of a triangle is called ampik-ampik. The wood under ander is called lambang and under lambang there is jait pendek which is a pole that connects the front soko to the rear soko. The wood that connects the two lambang is called penglari and under penglari there is jait panjang, the pole connecting the left soko and right soko. The front and back of the tikel house has a roof supported by wood which named soko tepas. Soko tepas has a smaller surface than a pillar in a house and supports a wooden roof called gelandar.

The component display from house of Using Banyuwangi as shown below.

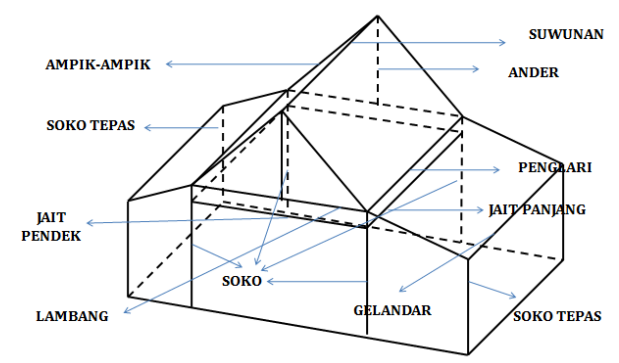

Fig. 4. Components from House of Using Banyuwangi (Hariastuti, et al., 2019:78)

House of Using Banyuwangi also contains three main parts of the house, namely mbyale (part to receive guest), njerumah (inside the house including bedrooms and living rooms), and pawon (kitchen part).
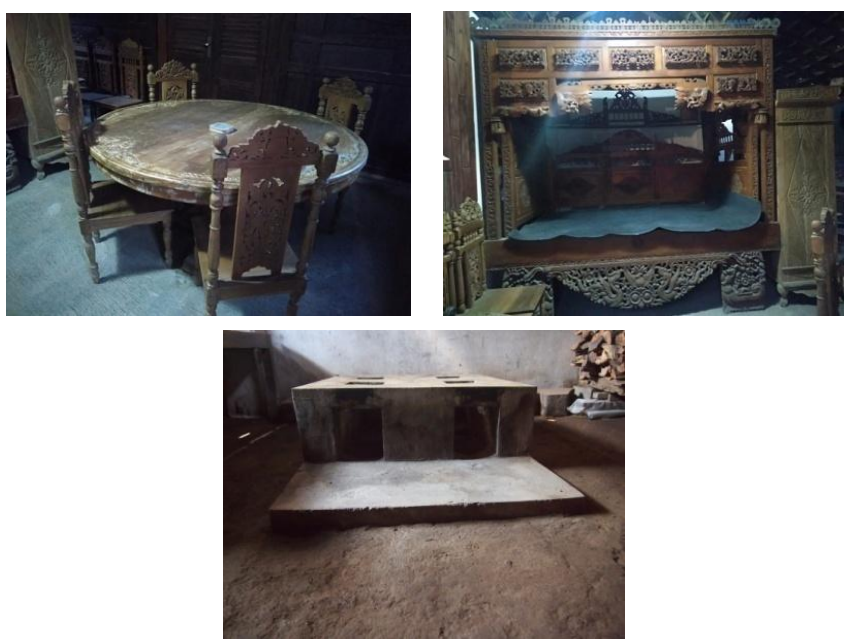

Fig. 5. Main parts from House of Using Banyuwangi (Mbyale, Njerumah, and Pawon)

The existence from house of Using Banyuwangi contains the concept of geometry, including: (1) the concept of two and three-dimensional geometry; (2) the concept of congruence; (3) the concept of transformation, (4) the concept of fractal, and (5) the application of phytagorean theorem (Hariastuti, 2018:20; Hariastuti, et al., 2019:78). Besides that, from the house of Using Banyuwangi, it can also be identified the concept of numerating and counting operations of simple numbers such as addition and multiplication. For example, students can count the number of soko in a house of Using Banyuwangi then determine the amount of wood needed for soko if more than one house of Using Banyuwangi will be built.

Mathematical concepts identified from house of Using Banyuwangi show that culture is not just about activities carried out by a shared community and hereditary that contain moral values, social, religious, artistic, etc, but culture also includes activities that can be used as a basis for learning. Balamurugan (2015:716) stated "culture can determine the student's feeling toward participation in class discussion, initiating questions, acceptance of authority, memorization of facts, seeking innovative ways of understanding, and many other aspects of classroom education". Based on this opinion, it can be concluded that Using Banyuwangi culture also has an important role in increasing student potential in the learning process, specially in learning mathematics.

The study of mathematical concepts practiced in culture is commonly known as ethnomathematics. Abah (2018:165) confirms his opinion about the relationship between culture and mathematics as follows. "As part of culture, mathematics consist of all the mathematic knowledge, views and skills that a certain people own collectively, with the purpose of keeping these alive and perhaps expanding them as a goal for general education. On the other hand, mathematics as subculture is the culture that is specific for people who have had training in mathematics as a science." The existence of mathematics in culture makes it necessary to implement culture in learning as a means of understanding mathematical concepts which is still considered abstract by students.

In general, mathematics tends to be presented as abstract knowledge and make students less understand the material presented by the teacher. This was confirmed by Rosa \& Gavarrete (2016:24) that "mathematics tends to be presented as a set of objective and universal facts and rules; it is commonly viewed as culture free and not considered a socially and culturally constructed discipline". This opinion shows the mathematical and cultural conditions which are often regarded as two things that have no connection. These conditions became the reasons for bringing up ethnomathematics in order to bridge mathematics and culture, especially in leraning.

Albanese \& Perales $(2015: 1)$ stated that "ethnomathematics is a research program that focuses on the relationships between mathematics and culture". The relationship between mathematics and culture makes ethnomathematics have a goal to combine mathematics and culture in the form of learning. As stated by Balamurugan (2015:717) "ethnomathematics aims to draw from the students' cultural experiences and practices of the individual learners, the communities, and the society at large".

D'Ambrosio (2001:308) explain the concept of ethnomathematics as a conceptual approach to learning mathematics as follows. "Ethnomathematics is an approach of teaching and learning mathematics which builds on the students' previous knowledge, background, the role his environment plays in terms of content and method, and his past and present experiences of his immediate environment and the approach could be in a practical way." The opinion 
shows that ethnomathematics can be the basis in the culture-based mathematics learning process as long as mathematical concepts in the culture can be explored and identified beforehand. To be able to identify mathematical concepts in culture requires an understanding of mathematics and its role in culture.

Abah (2018:164) stated that "mathematics can be described as an organized active thinking, which involves the search for patterns and relationships that may be expressed in symbols". While Albanese \& Perales (2015:2) describe mathematics as "the product of a socio-historical and cultural process that has been developed with contributions from various societies and cultures, and has given rise to what we now understand in the school context". Both statements describe mathematics as an organized form of thought in patterns and symbols that can be obtained from cultural processes that have developed in society and can be integrated in learning.

The existence of patterns and symbols in mathematical concepts makes mathematics a form of language that requires a certain understanding in the delivery process. Mathematics as a language that is very different from the language understood by students in school, need to be understood in a language that students have known before. Students recognize their first language as a mother tongue. Mother tongue is needed at the beginning of the learning process, especially in elementary learning, to help students understand other languages used in learning.

UNESCO in 2003 stated "that no language can take the place of mother tongue in education and that no educational system can afford to disregard it without serious detriment to the mental and social development of the child" (Anyagh, et al., 2016:94-95). Language is a symbol system with certain meanings that are used as communication tools. Suhardin, et al. (2017:34) refer to mother tongue as the first language mastered by someone and used to interact with their family and environment, and express ideas, self-expression, and feelings. Mother tongue or language known by students since childhood and used in various daily activities commonly called L1. While the language used in learning and different from the mother tongue is commonly known as L2.

In general, language in learning is a foreign language for students if the first language known to students is not the same as the language used in learning. If $\mathrm{L} 1$ is different from L2 then the L2 understanding process is needed before students are in the process of understanding learning. The use of mother tongue in learning, is a means to facilitate the delivery of learning concepts from teachers and learning resources to students. This was confirmed by Anyagh, et al. (2016:95) "for a student to achieve better in school he/she must have a good command of the language of teaching and learning". For this reason mother tongue is needed as a tool in understanding abstract learning concepts for students.

Mother tongue has a big role, especially in students who are new to the learning process at the elementary level. Ibda (2017:195) stated that "conceptually in Indonesia, mother tongue is not taught in schools, especially in elementary because they already use Indonesian whose category is second language and the process of obtaining it through language learning". However, at several levels of learning, mother tongue is still taught as local content which is to preserve the language which is generally the regional language in the region.

Understanding in language influences understanding in other learning, one of which is mathematics. "Doing mathematics is not just the manipulation of the appropriate mathematical symbols, a misunderstanding often found in schools" (Clarkson \& Idris, 2006:74). Missunderstanding in mathematical symbols, among other, occur because of students' lack of understanding of the mathematical language explained in the learning language (Indonesian). So, mother tongue is needed in learning methematics in order to clarify the understanding of concepts that are still abstract for students.

Based on the discussion, the development of mathematics teaching material based on the house of Using Banyuwangi that used Using language which is the mother tongue of the Using Banyuwangi community is carried out.

\section{RESEARCH METHOD}

This study is a development research conducted with the cultural background of Using Banyuwangi. The development is carried out with the ADDIE model which aims to develop mathematics teaching material based on house of Using Banyuwangi with mother tongue. The study was conducted based on the following flow.

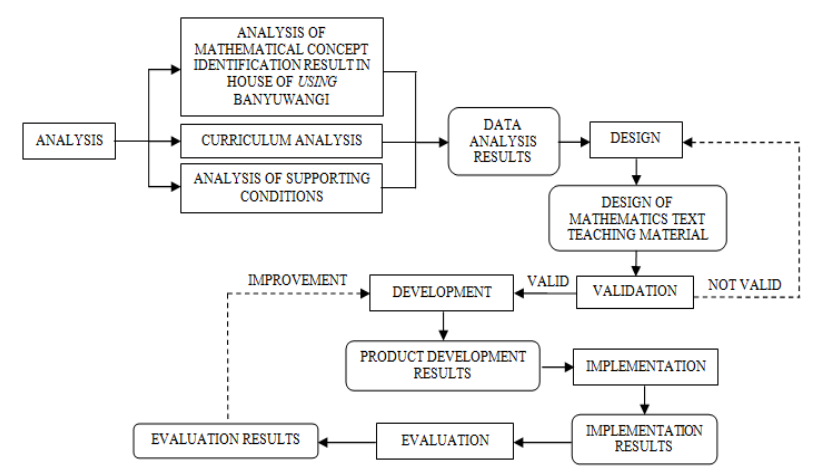

Fig. 6. Research Flow

Identification of mathematical concepts in the house of Using Banyuwangi were analyzed based on previous research. Curriculum analysis is carried out on the basic mathematics competencies of grade 2 elementary schools. The level selection is based on the results of interviews and observations at 5 elementary schools in Banyuwangi which show that students in grade 2 have more stable reading, writing, and understanding vocabulary skills better than grade 1 students. The curriculum is analyzed by adjusting basic mathematics competencies in grade 2 with mathematical concepts obtained from house of Using Banyuwangi. While the learning support conditions are analyzed through interviews with low grade teachers at five elementary schools in Banyuwangi where there are still many Using Banyuwangi tribes living there. The five elementary schools represent five regions in Banyuwangi, namely Public Elementary School (PES) Kenjo on Glagah District (representing the west region of Banyuwangi), PES 1 Sukojati on Blimbingsari District (representing the eastern region of Banyuwangi), PES 1 Gumirih on Singojuruh District (representing the south region of Banyuwangi), PES 3 Boyolangu on Giri District (representing the central region of Banyuwangi), and PES 1 Pesucen on Kalipuro District (representing the northern region of Banyuwangi). The results of the analysis are used as material for making design for mathematics teaching material.

Design of mathematics teaching learning is made in the form of learning texts and evaluation instruments. Design 
results were further validated by expert validators consisting of: (1) one Banyuwangi cultural practitioner and one Using language teacher, as a validator of the Using language context and construct; (2) two elementary school teachers, as validators of the context and construct of learning text material. The Banyuwangi cultural practitioner chosen as validator has the following criteria: (1) communication fluently using Using language; (2) has competence in at least one of the cultures that exists in Banyuwangi; and (3) has been involved in a culture that he has understood for a minimum of 10 years. Whereas the Using language teacher who was determined as a validator was selected with the following criteria: (1) having a background from the Using tribe; (2) fluent in communicating with Using language both oral and written; and (3) have taught Using language subjects for a minimum of 5 tears in elementary school. The elementary school teacher who is determined as a validator has the following criteria: (1) at least has been a class teacher in the elementary school for 5 years in Banyuwangi; (2) have taught at least a low class for 1 year.

If the validation results meet the predetermined criteria, then the process continues on the development of a mathematics teaching material based on house of Using Banyuwangi culture using the mother tongue. When the result of the validation have not met the specified criteria, a design revison is carried out. The results of further product development are implemented in Public Elementary School 1 Gumirih because it is located in one of the districts in Banyuwangi which is still inhabited by Using Banyuwangi tribes and the main language of communication used is the Using language. There are 8 students who become research respondents.The results of implementation become the evaluation material for developing the mathematics teaching material. While the results of the evaluation become material for product improvement for the development of Using Banyuwangi culture-based mathematics teaching materials.

\section{RESULTS AND DISCUSSION}

This research is a development study with the ADDIE model conducted within 6 months, from July to December 2019. The first stage is done by analyzing the suitable of mathematical concepts in the house of Using Banyuwangi with basic competencies that are used as a reference for learning in elementary school, especially low class. The respondents consisted of 14 low grade teachers from 5 elementary schools in Banyuwangi. And 8 second grade students from Public Elementary School 1 Gumirih Banyuwangi.

\subsection{Results of Analysis of Culture, Curriculum, and Supporting Condition}

Material in second grade is choosen because of teacher's consideration at the school which stated that students in grade 2 are fluent in basic literacy (reading and writing) and start learning to analyzed reading material. This is a good reason to develop mathematics teaching materials based on house of Using Banyuwangi culture using mother tongue at that level. Analysis of mathematical concepts in the house of Using Banyuwangi and curriculum provides the results of the selection of two competencies as material for developing mathematics text teaching materials, namely: (1) explain the concept and carry out the process of adding and subtracting chopped numbers up to 999, and use it to solve problems of daily life; and (2) explain the concept and carry out the process of multiplication and division of chopped numbers with a product of up to 100, and use it to solve problems of daily life. The competency was chosen because the components of the house of Using Banyuwangi can be used as a contextual object to be a basis for learning the selected concepts.

Analysis of learning support conditions conducted through interviews with low grade teachers in Public Elementary School (PES) Kenjo, PES 1 Sukojati, PES 1 Gumirih, PES 3 Boyolangu, and PES 1 Pesucen provide results that support the making of mathematics teaching materials using mother tongue. The results of interviews with three low grade teachers in PES Kenjo showed that learning in low grades had the following characteristics: (1) it requires reinforcement of character learning; (2) requires strengthening literacy ability (reading and writing); (3) requires an understanding of learning using mother tongue; and (4) needed real objects as learning media to concretize the concepts of learning.

Character learning is needed for students to get accustomed to greeting when entering rooms, pray before starting learning, singing national songs, memorizing country text and symbols, and so on. Strengthening literacy ability needs to be done because there are still many students in grades 2 and 3 who cannot read and write. This is both a burden and a challenge for teachers at this level because learning is not only focused on the learning process, but also divides the attention of students who are not yet fully skilled at reading and writing. These constraints cause teachers to have difficulty in understanding other learning concepts, such as mathematics.

The concept of learning is also difficult to convey because of the language barrier. Generally low class students are still accustomed to communicating using Using language, which is the mother tongue in the Kenjo village. But not all teachers understand the Using language due to differences in backgrounds and regions of origin of these teachers. So that if the teacher understands Using language, the learning process is carried out using a mixed language (between Indonesian and Using language). But when the teacher does not understand the Using language (understand the meaning but cannot convey), the teacher will use another mixed language (Indonesian with Javanese or Madura language).

In some learning, such as mathematics and science, students also needed the real objects to be able to understand the intended concept. Real objects can be learning media that are intentionally made or purchased by the teacher, or objects that are close to students' daily lives, such as gravel, broom sticks, corn kernels, etc. The existence of real objects is expected to make abstract concepts into concrete.

Interviews conducted with three low grade teachers in Public Elementary School 1 Sukojati-Blimbingsari District showed that learning difficulties experienced by teachers because students do not fully understand Indonesian so learning needs to be assisted with Using language. Learning in low class thematic-based caused the teacher must do learning with mixed languages (Indonesian and Using) so students better understand the expected learning concepts. However, not every concept can be explained using the Using language. In mathematics learning. teachers feel that many concepts are easier to convey in Indonesian.

Example of delivering mathematical material with Using language in grade 2 on multiplication material, i.e. if in Indonesian it is said that "twice three $(2 \times 3)$ means three times is added twice", then it is delivered in Using language as : 
Loro ping telu $(2 \times 3)$ berarti hang dijumlah iki hang telu, dudu hang loro. Dadi hang sebelah tengen hang dijumlah, ping hang ngarepe iki mau. Kadung misal telu ping loro, loro ne ping telu.

Meaning: two times three means three sums twice, not two added three times. So the right side is is added to the left. If three times two, then two are added three times.

According to three teachers at Public Elementary School 1 Sukojati, difficulties in the process of learning mathematics at a low level including there are still students who are not skilled in reading and writing, the need for communication tools (language) that are easily understood by students, and the need for instructional media to make abstract concepts more visible to students (such as the use of money in addition and substraction). The difficulty also brings out the characteristics of learning in low class, namely the use of mother tongue (Using language) is more dominant as a commucation tool. Learning also cannot be done seriously because students get bored easily. So the teacher must be more creative to providing interesting activities in learning.

Interviews with three low grade teachers in Public Elementary School Gumirih-Singojuruh showed that learning in the low clases has unique characteristics, which still need to provide character reinforcement and ability to read and write, and the need to use mother tongue to understand the concept of learning. Generally teachers in the lower classes are quite understanding and able to communicate with Using language, so learning can be done using mixed languages (Indonesian and Using language).

Based on the results of the Using language training for elementary school teachers and regulations on the use of traditional clothes for teachers and students in Banyuwangi, then every Tuesday at Public Elementary School 1 Gumirih is made a rule to use traditional clothing and communicate Using language for one day. These provisions are made for "nguri-uri" (preserving) the use of Using language. Thus students and teachers are expected to love their culture more and be able to communicate in learning with Using language.

In mathematics learning, the teacher is not only constrained by the language of instruction but also the abstract concepts learning that still require the use of instructional media such as broom sticks, gravel, leaves, etc. The difficulty of understanding concept also causes students uncomplete the study assignment for each meeting. For this reason the teacher must make every effort so that students can understand the material presented, and the tasks in each learning can be completed.

Interviews conducted with three low grade teachers in Public Elementary School 3 Boyolangu-Giri showed that understanding of learning materials in low grade requires support from the mother tongue (Using language). The use of mother tongue is needed until students in high class (grades 4 through 6). This is the process of "nguri-uri" culture and also a supporting factor for students' understanding. However, them Indonesian language continues to be the main introduction to learning.

Another teacher's difficulty experienced is the condition of students who are still in the process of understanding concrete objects with abstract learning material, such as mathematics. The teacher uses instructional media as a tool to solve the problem. Learning media used are objects that are close to students' daily lives such as broom sticks and gravel. For example is the understanding of the concept of comparison in grade 1 , the teacher uses pebble to determine that "four is more than three". The teacher's way of explaining is by asking students to take four pebbles, then take three pebbles. Through this process the teacher can make students understand the concepts of "more than", "less than", or "equal". But students in grade 1 are still unable to write sentences that state the comparison. This happens because students' understanding of vowels and consonants is still limited.

The use of Using language which is a mother tongue and learning media is still needed until students are in high class. For this reason, teacher tries to be able to provide variations in the learning process by using mixed languages and learning media. Parental support is also needed so students can complete learning assignment. This is not in accordance with the condition of the majority of parents with low education (maximum graduating from elementary school) and the need for parents to work, causing the continuation process of learning at home to run less optimally.

Interviews conducted with two low-grade teachers at Public Elementary School 1 Pesucen-Kalipuro showed that teachers did not have much trouble in understanding their writing and reading skills. This happens because learning in kindergarten has made students able to read and write. Learning done by the teacher in the class also does not accustom the use of Using language as a companion language. Students are accustomed to using Indonesian communication and learning. Teacher is still hesistant in using the Using language as a communicating tool because some students at the school come from outside the Pesucen village area whose daily language of instruction is not Using language. The use of Using language as an introductory language is considered as a barrier. However, Using language as a mother tongue is still used in the process of communication between students, and between teachers and students outside of learning hours.

The results of interviews with the teachers indicate the need to use Using as a language of instruction in low-grade learning. Students also need real objects to understand concepts, especially mathematics. One of the real objects that can be used in mathematics learning is traditional house of Using Banyuwangi, known as "house of Using Banyuwangi". This culture is close to students' daily lives so it can be used as a basis for making mathematics teaching materials.

\subsection{Product Design and Validation Process Results}

House of Using Banyuwangi theme then developed into mathematics teaching materials which was translated in Using language. Product design produces a draft of mathematics teaching materials in Using language with the title "Umahe Wong Using Banyuwangl".

Mathematics Teaching Materials in Using language are then validated to find out the validity of the language context, the context of the material, and the layout of the text. The results of the language context indicate the feasibility of the learning text. While the results of the validation in the material and the layout of the text not decent enough because too much information is given in the text, font size is too small, and writing too tight (space is not large enough), and visual images are less clear. 


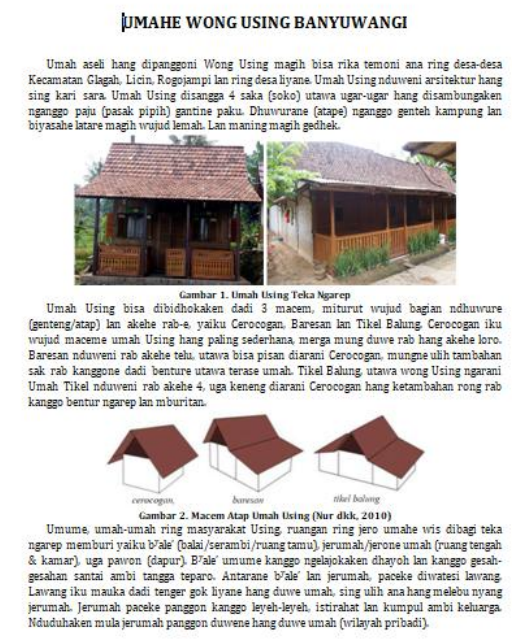

Fig. 7. Mathematics Teaching Materials "Umahe Wong Using Banyuwang?" Page 1

Repairs carried out based on the results of the asessment of the validation of the context of the material and the layout of the text. The improvement process is carried out together with the development process. The revision is done by reducing the information provided in the text, enlarging the size of the letters used (from letters measuring $12 \mathrm{pt}$ to $14 \mathrm{pt}$ ), enlarge the use of spaces (from space 1 to space 1.15), also enlarge, replace, and add visual images. Visual images added are images of house of Using Banyuwangi which are known by students, the house of Using Banyuwangi in Gumirih Village. Results of revision of learning texts "Umahe Wong Using Banyuwangi" obtained as follows.

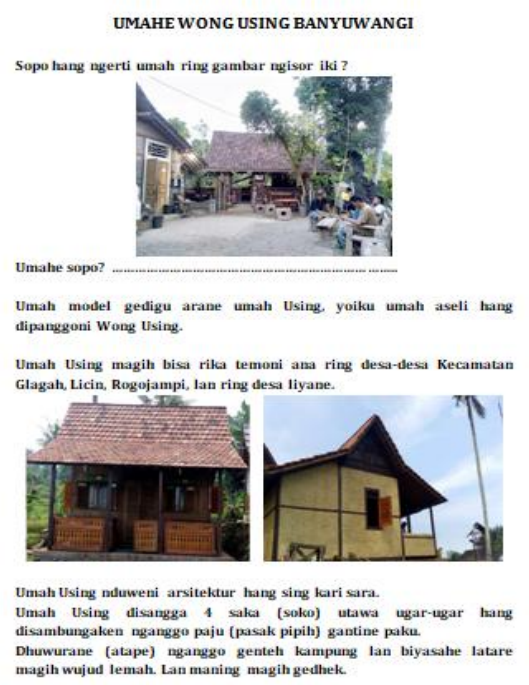

Fig. 8. Revised of Mathematics Teaching Materials "Umahe Wong Using Banyuwangi" Page 1

\subsection{Learning Implementation}

Implementation of mathematics teaching materials based on house of Using Banyuwangi using mother tongue with the title "Umahe Wong Using Banyuwangi" done in grade 2 Public Elementary School 1 Gumirih. This implementation was conducted to determine the effectiveness of the use of mathematics teaching materials based on house of Using Banyuwangi using the mother tongue in elementary schools. Effectiveness of mathematics teaching materials is identified from students' understanding of the learning information provided (it is known from the answers given by students when the teacher gives questions about the house of Using Banyuwangi) and the ability of students to understand sentences in the exercises (known from the ability of students to answer the questions given).

Learning is carried out by teachers who are fluent in Using language. Implementation respondents were 8 students.

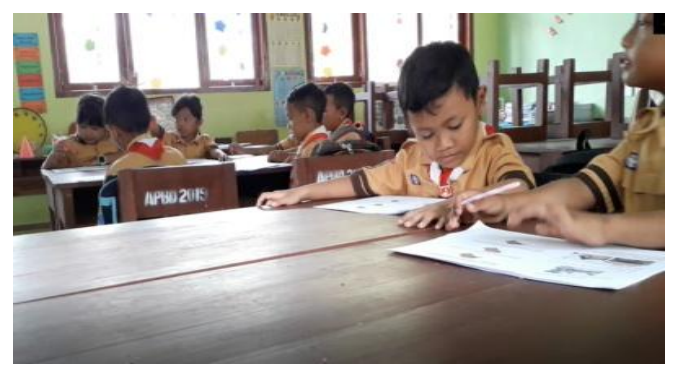

Fig. 9. Learning Implementation (Learning is Carried Out with Mathematics Teaching Materials Based on House of Using Banyuwangi and Mother Tongue)

\subsection{Evaluation of The Product and Its Implementation}

Implementation results show that: (1) students must still be guided to read the sentences given in the mathematics teaching materials (students do not have the will to read themselves); (2) students understand the information provided in the mathematics teaching materials, it is indicated by 6 out of 8 students being able to answer the questions given by the teacher in the process of repeating the discussion; (3) students can complete the problem exercises given together. In this case students are still having trouble connecting the given conditions with mathematical concepts needed for problem solving. Students tend to say many objects are asked rather than using the concept of addition or multiplication. Only one student can quickly relate the given conditions to the concepts of addition and multiplication needed for problem solving.

The results of the implementation showed that the use of mathematics teaching materials based on house of Using Banyuwangi and mother tongue in learning at Public Elementary School 1 Gumirih had not been fully effective in understanding students. This is shown from students who are still having trouble connecting the given conditions with the mathematical concepts that must be resolved in the material counting operations. For this reason, it is necessary to improve the products, especially in compiling teaching materials based on house of Using Banyuwangi.

\subsection{Discussion}

Based on the result of the analysis of the identification of mathematical concepts in house of Using Banyuwangi, curriculum, and learning support conditions, show that learning mathematics at the elementary level requires real objects. This is in accordance with the opinion of Ojose (2011:93) which states that "students should be offered real-world situations relevant to them, either real-world situations that help them function as informed and intelligent citizens or real-world situations that are relevant to their areas 
of interest, either professionally or educationally". Etnomathematics are presented as objects that make abstract mathematical concepts become more real in learning.

The theme of house of Using Banyuwangi was raised in mathematics teaching material because it is a cultural object that is close to the daily lives of students in the Using Banyuwangi community. This is supported by one of the principles of making teaching materials that must reflect real life as much as possible (Aydin \& Aytekin, 2018:27), as well as one of the principles for determining learning themes that must pay attention to the students' closest environment (Ahmadi \& Amri, 2014:211). The use of house of Using Banyuwangi themes that are contextual to students' daily lives will also make the learning more meaningfull. This is consistent with the opinion of Gazali (2016:185) which states that the use of contextual problems will make children learn more meaningful because they work and experience things themselves not just knowing.

Using languages as the mother tongue of the Using Banyuwangi tribe is used as the language of instruction in the text of the mathematics teaching material developed. The use of Using language is done to achive a more optimal understanding of learning. This condition is different when compared to using Indonesian as the language of instruction. This is supported by the results of research that states that learning mathematics at the elementary school level requires the assistance of mother tongue as an effective strategy in improving performance, internalizing mathematical language, and making mathematics a subject that is not feared by students (Njoroge, 2017:133; Omoniyi \& Olabode, 2013:542).

The product of the results of the development of mathematics teaching materials based on house of Using Banyuwangi and mother tongue, is still not fully effective because there are students are still having difficulty connecting the real conditions of learning themes (in this case the house of Using Banyuwangi) with mathematical concepts needed for problem solving. For this reason, improvements are needed in the conceptualization of the text of mathematics teaching materials so that it can connect between learning themes and mathematical concepts that are expected to be understood by students.

\section{CONCLUSION}

The development of mathematics teaching material based on house of Using Banyuwangi with mother tongue can be done using the ADDIE development model. The results of the development show that the mathematics teaching materials has not been fully seffectively implemented in learning because students are still having trouble connecting real objects with the concept of learning mathematics. Repairs needed in the process of developing of mathematics teaching material so that it can be used in futher learning.

Based on the results of previous research on the identification of mathematical concepts in Banyuwangi culture such as the Gandrung dance and the results of the development of teaching materials that has been done, it is recommended to develop the making of mathematics teaching material with other Banyuwangi cultural bases that are close to students' daily lives.

\section{ACKNOWLEDGEMENTS}

Acknowledgments are given to the cultural expert and art practitioners in Banyuwangi who were involved in this research.

\section{REFERENCES}

Abah, J. A. (2018). Mathematics in the Cultural Practices of the Orokam People of Nigeria:Insights into the Educational Relevance of the I'tche Game. International Journal For Innovative Research In Multidisciplinary Field, Vol. 4, Issue $6,164-171$.

Ahmadi, I. K., \& Amri, S. (2014). Pengembangan \& Model Pembelajaran Tematik Integratif. Jakarta: Prestasi Pustakaraya.

Albanese, V., \& Perales, F. J. (2015). Enculturation with Ethnomathematical Microprojects: From Culture to Mathematics. Journal of Mathematics \& Culture, Vol. 9, Issue 1, 1-11.

Anyagh, I. P., O'kwu, E. I., \& Imoko, B. I. (2016). Impact of Using Tiv Language for Teaching and Learning Mathematics on Students' Achievement in Benue State. Asia Pacific Journal of Education, Arts and Sciences, Vol. 3 No. 1 , 94-98.

Aydin, A., \& Aytekin, C. (2018). Teaching Material Development and Meeting the Needs of the Subject: A Sample Application. International Education Studies, Vol. 11, No. $8,27-38$.

Balamurugan, M. (2015). Ethnomathematics; An Approach For Learning Mathematics From Multicultural Perspectives. International Journal Of Modern Research And Reviews, Vol. 3, Issue 6, 716-720.

Clarkson, P. C., \& Idris, N. (2006). Reverting To English To Teach Mathematics: How Are Malaysian Teachers And Students Changing In Response To A New Language Context For Learning? Journal of Science And Mathematics Education In S.E. Asia, Vol. 29, No. 2 , 69-96.

D'Ambrosio, U. (2001). What is Ethnomathematics and how can it help children in schools? Teaching Children Mathematics, Vol. 7, NO. 6, 308-310.

Gazali, R. Y. (2016). Pengembangan Bahan Ajar Matematika untuk Siswa SMP Berdasarkan Teori Belajar Ausubel. PYTHAGORAS: Jurnal Pendidikan Matematika, Vol. 11, No. 2 , 182-192.

Hariastuti, R. M. (2018). Kajian Konsep-Konsep Geometris Dalam Rumah Adat Using Banyuwangi Sebagai Dasar Pengembangan Pembelajaran Kontekstual Berbasis Etnomatematika . Aksioma, Vol. 7, No. 1, 13-21.

Hariastuti, R. M., Budiarto, M. T., \& Manuharawati. (2019). From Culture to Classroom: Study Ethnomathematics in House of Using Banyuwangi. International Journal of Trends in Mathematics Education Research, Vol. 2, No. 2, 76-80.

Hidayatulloh, N., \& Hariastuti, R. M. (2018). Kajian Etnomatematika Angklung Paglak Banyuwangi . Jurnal Aksioma, Vol. 7, No. 3 , 380-389.

Ibda, H. (2017). Urgensi Pemertahanan Bahasa Ibu di Sekolah Dasar. Shahis, Vol. 2, No. 2 , 194-207.

Indiarti, W. (2015). Kajian Mengenai Desa Kemiren Sebagai Penyangga Tradisi dan Kearifan Lokal Masyarakat Osing. In S. Anasrullah, Jagat Osing: Seni, Tradisi dan 
Kearifan Lokal Osing (pp. 139-156). Banyuwangi: Rumag Budaya Osing-Lembaga Masyarakat Adat Osing .

Njoroge, M. C. (2017). The Efficacy of Using Mother Language in the Teaching of Mathematics and Science in Primary Schools: Evidence from Grade One Classrooms in Kenya. Journal of Applied Linguistics and Language Research, Vol. 4, No. 8 , 133-150.

Nur, T. K., Antariksa, \& Sari, N. (2010). Pelestarian Pola Permukiman Masyarakat Using di Desa Kemiren Kabupaten Banyuwangi. Jurnal Tata Kota dan Daerah, Vol.2, No. 1, 59-73.

Ojose, B. (2011). Mathematics Literacy: Are We Able To Put The Mathematics We Learn Into Everyday Use? Journal of Mathematics Education, Vol. 4, No. 1 , 89-100.

Omoniyi, I. O., \& Olabode, T. O. (2013). Effect of Mother Tongue and Mathematical Language on Primary School Pupils Performance in Mathematics. Journal of Emerging Trends in Educational Research and Policy Studies (JETERAPS), Vol. 4, No. 3 , 542-546.

Rosa, M., \& Gavarrete, M. E. (2016). Popysemic Interactions between Ethnomathematics and Culturally Relevant Pedagogy. In M. Rosa, U. D'Ambrosio, D. C. Orey, L. S. Alangui, P. Palhares, \& M. E. Gavarrete, Current and Future Perspectives of Ethnomathematics as a Program (pp. 23-24). Switzerland: Springer International Publishing.

Sandhi, N. S., Trapsilasiwi, D., Yudianto, E., Suharto, \& Sugiarti, T. (2018). Etnomatematika Pola Tarian Jejer Jaran Dawuk Banyuwangi Sebagai Inspirasi Pengembangan Paket Tes Geometri. Kadikma, Vol. 9, No. $3,160-170$.

Suhardin, Juliangkary, E., \& Aguasfianuddin. (2017). Pengaruh Penggunaan Bahasa Ibu dalam Konteks Belajar Mengajar Matematika terhadap Daya Serap dan Motivasi Belajar Siswa Kelas VIII SMP Negeri 1 Ropang Tahun Pelajaran 2016/2017. JMPM Vol. 5, No. 1 , 33-38.

Wibowo, A. (2015). Arsitektur Kerakyatan dari Masyarakat Blambangan. In M. Anasrullah, Jagat Osing: Seni, Tradisi, \& Kearifan Lokal Osing (pp. 59-70). Banyuwangi: Rumah Budaya Osing-Lembaga Masyarakat Adat Osing. 